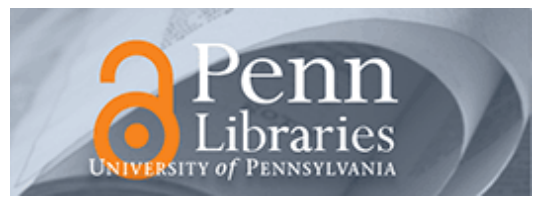

University of Pennsylvania

ScholarlyCommons

Management Papers

Wharton Faculty Research

$12-1999$

\title{
Comparative Economic Organization-Within and Between Countries
}

Witold J. Henisz

University of Pennsylvania

Oliver E. Williamson

Follow this and additional works at: https://repository.upenn.edu/mgmt_papers

Part of the Business Administration, Management, and Operations Commons, International Business Commons, and the Management Sciences and Quantitative Methods Commons

Recommended Citation

Henisz, W. J., \& Williamson, O. E. (1999). Comparative Economic Organization-Within and Between Countries. Business and Politics, 1 (3), 261-278. http://dx.doi.org/10.1515/bap.1999.1.3.261

This paper is posted at ScholarlyCommons. https://repository.upenn.edu/mgmt_papers/168

For more information, please contact repository@pobox.upenn.edu. 


\title{
Comparative Economic Organization-Within and Between Countries
}

\author{
Abstract \\ This paper explores the implications of going beyond transaction cost theory's implicit focus on domestic \\ investors to include multinational actors. As developed herein, the discriminating alignment between the \\ level of hazards (contractual and/or political) and the mode of governance carries over. In the open- \\ economy context, such an alignment reflects the hazards that arise from the nature of the transaction and \\ those that arise from the nature of the political and regulatory environment.

\section{Disciplines} \\ Business Administration, Management, and Operations | International Business | Management Sciences \\ and Quantitative Methods
}




\title{
Comparative Economic Organization-Within and Between Countries
}

\author{
WITOLD J. HENISZ ${ }^{1}$ \& OLIVER E. WILLIAMSON ${ }^{2}$ \\ ${ }^{1}$ University of Pennsylvania \& ${ }^{2}$ University of California at Berkeley
}

\begin{abstract}
This paper explores the implications of going beyond transaction cost theory's implicit focus on domestic investors to include multinational actors. As developed herein, the discriminating alignment between the level of hazards (contractual and/or political) and the mode of governance carries over. In the open-economy context, such an alignment reflects the hazards that arise from the nature of the transaction and those that arise from the nature of the political and regulatory environment.
\end{abstract}

\section{Introduction}

We examine comparative economic organization through the lens of transaction cost economics. The argument proceeds in four parts.

We begin by holding the institutional environment (rules of the game) constant and examine the organization of economic activity as between alternative modes of governance-markets, hybrids, firms and bureaus. We then examine the effects of changes in the institutional environment, over time or between countries, on investment and organization by domestic firms. We then extend our analysis to examine investment and contracting in which the multinational corporation is a key actor. Investment and contracting in various countries that have recently experienced economic crises which have altered investor's perceptions of the institutional environment are then briefly examined.

In effect, ours is a bottom-up view of the nation-state in which the microanalytics of organization are featured. We do not focus on familiar macroeconomic conditions, such as the aggregate level of investment, the rate of growth, unemployment, and the like. Rather, we ask how does economic activity get organized under different institutional regimes. An interesting by-product of this exercise is that it ought to be possible to infer, from knowledge of the

Correspondence: Witold J. Henisz, Assistant Professor of Management, The Wharton School, University of Pennsylvania, 2021 Steinberg Hall-Dietrich Hall, Philadelphia, PA 19104-6370,USA. E-mail: henisz@ wharton.upenn.edu, or Oliver E. Williamson, Edgar F. Kaiser Professor of Business; Professor of Economics; and Professor of Law, University of California at Berkeley, Berkeley, CA 94720, USA. E-mail: owilliam@ haas.berkeley.edu 
organization of economic activity in a country, some of the gross features of the institutional environment.

Our efforts to link the institutional environment and the organization of economic activity should be of interest at several levels: to economists seeking mechanisms to link variation in the structure of a nation's political institutions and economic outcomes; to managers seeking to expand their operations beyond their home countries; and to policymakers seeking to influence or shape the evolution of economic activity in their country. By jointly considering the effect of political and contractual hazards on economic organization, this paper advances previous work in this domain that has traditionally considered the impact of variation in the institutional environment or in the characteristics of the transaction on governance. Even in those studies that examine both effects simultaneously, the mechanisms by which the hazards emanating from the characteristics of the transaction and from the institutional environment may interact have received only preliminary attention.

The institutional environment itself operates at two levels: an informal level-the norms, customs, mores, religion; and a formal level-the polity, judiciary, laws of contract and property. Of these two, we emphasize the latter. It is important to realize that the institutional environment is rich: a lot of things have a bearing on the efficacy of contract and organization. This variety can be treated in both piecemeal and composite ways. We do both.

\section{The baseline setup}

Transaction cost economics is a comparative contractual approach to economic organization in which the action resides in the details of transactions on the one hand and governance on the other. Given that all complex contracts are unavoidably incomplete (by reason of bounded rationality) and that contract as mere promise, unsupported by credible commitments, is not self-enforcing (by reason of opportunism ${ }^{1}$ ), the question is which transactions should be organized how.

Much of the predictive content of transaction cost economics works through the discriminating alignment hypothesis, according to which transactions, which differ in their attributes, are aligned with governance structures, which differ in their costs and competences, so as to effect a (mainly) transaction cost economizing result. Implementing this requires that transactions, governance structures, and transaction cost economizing all be described. What are the defining attributes of transactions? What are the attributes with respect to which governance structures differ? What main purposes are served by economic organization? How is transaction cost economizing accomplished?

According to John R. Commons, 'the ultimate unit of activity ... must contain in itself the three principles of conflict, mutuality, and order. This unit is a transaction' ${ }^{2}$ Transaction cost economics concurs that the transaction is the basic unit of analysis and regards governance as the means by which order is

1. 'Self-interest seeking with guile' (Williamson, 1996, p. 6).

2. Commons (1932), p. 4. 
accomplished in a relation in which potential conflict threatens to undo or upset opportunities to realize mutual gains.

The problem of conflict on which transaction cost economics originally focused is that of bilateral dependency. ${ }^{3}$ The organization of transactions that are supported by generic investments is easy: classical market contracting works well because each party can go its own way with minimal cost to the other. Specific investments are where the problems arise. Contracts that are supported by durable investments in nonredeployable assets pose contractual hazards, in that one or both parties can defect from the letter or spirit of an agreement. That is true even if property rights are 'well defined', contract laws are 'well conceived', and the judiciary enforces the laws in a 'principled way'.

Thus even if property rights are well defined in general, some property rights are very hard to describe (it is not cost effective to describe them with greater precision) and hard to enforce (it is difficult for a court to be apprised of true underlying conditions). Property rights ambiguities thus remain even in a regime where best efforts to define and enforce property rights through the courts have been made. Similar considerations apply to contract law: there are limits on how exacting the law can be and how effectively it can be enforced by the courts.

The upshot is that a huge amount of property right protection and contract law enforcement is moved out of the courts and onto private ordering. As Marc Galanter has put it, in 'many instances the participants can devise more satisfactory solutions to their disputes than can professionals constrained to apply general rules on the basis of limited knowledge of the dispute'. ${ }^{4}$ The courts are thus reserved for purposes of ultimate appeal.

The alignment of transactions to alternative modes of private orderingprincipally markets, hybrids, and hierarchies - is where the main action resides. Taking adaptation (of autonomous and cooperative kinds) to be the central problem of economic organization, the basic alignment is that simple transactions (by which we mean those that pose few contractual hazards) will be organized in markets and that transactions thereafter move to hybrids and, eventually, to unified ownership (hierarchy) as contractual hazards build up. These regularities are shown by the solid governance cost schedules in Figure 1. When contractual hazards are low, more complex forms of organization are at a disadvantage since they incur 'added bureaucratic costs for which no benefits can be ascribed'. ${ }^{5}$ However, as contractual hazards increase, 'the high-powered incentives of the market impede adaptability ... and maladaptation costs are incurred. Although the transfer of such transactions from market to hierarchy creates added bureaucratic costs, those costs may be more than offset by the bilateral adaptive gains that result' ${ }^{6}$ The data are corroborative. ${ }^{7}$

3. See Williamson (1975) and Klein et al. (1978).

4. Galanter (1981), p. 4.

5. Williamson (1996), p. 106.

6. Williamson (1996), pp. 106-107.

7. See Shelanski and Klein (1995), Lyons (1995), and Crocker and Masten (1996). 


\section{Shift parameters for domestic investors}

The basic setup holds the institutional environment constant (and normally assumes that property rights and contract law regimes are strong). Comparisons within a country (over time) or between countries (cross-sectionally) can be made by introducing differences of property right and contractual kinds.

Unsurprisingly, more secure property rights regimes will elicit more investment in durable, nonredeployable assets as well as those assets with weak appropriability regimes, ceteris paribus. ${ }^{8}$ Also, contract law changes that shift the relative costs of governance will induce transactions to be moved into what have now become the (comparatively) lower cost modes.

By comparison with market and hybrid modes of governance, where interfirm contracting disputes are presented to the courts for purposes of ultimate appeal, hierarchy settles most of its own conflicts internally. Accordingly, changes in contract law will be concentrated on market and hybrid modes of governance. A change in contract law that improves the quality of enforcement will therefore reduce the governance costs of market and hybrid contracting as compared with hierarchy. More transactions will thus be mediated by spot and long-term contracts in regimes where contract enforcement works well. Such changes are shown by the move from solid to dashed lines in Figure 1.

Changes in intellectual property rights can be interpreted similarly. Where such property rights protection is weak, firms that engage in interfirm contracting

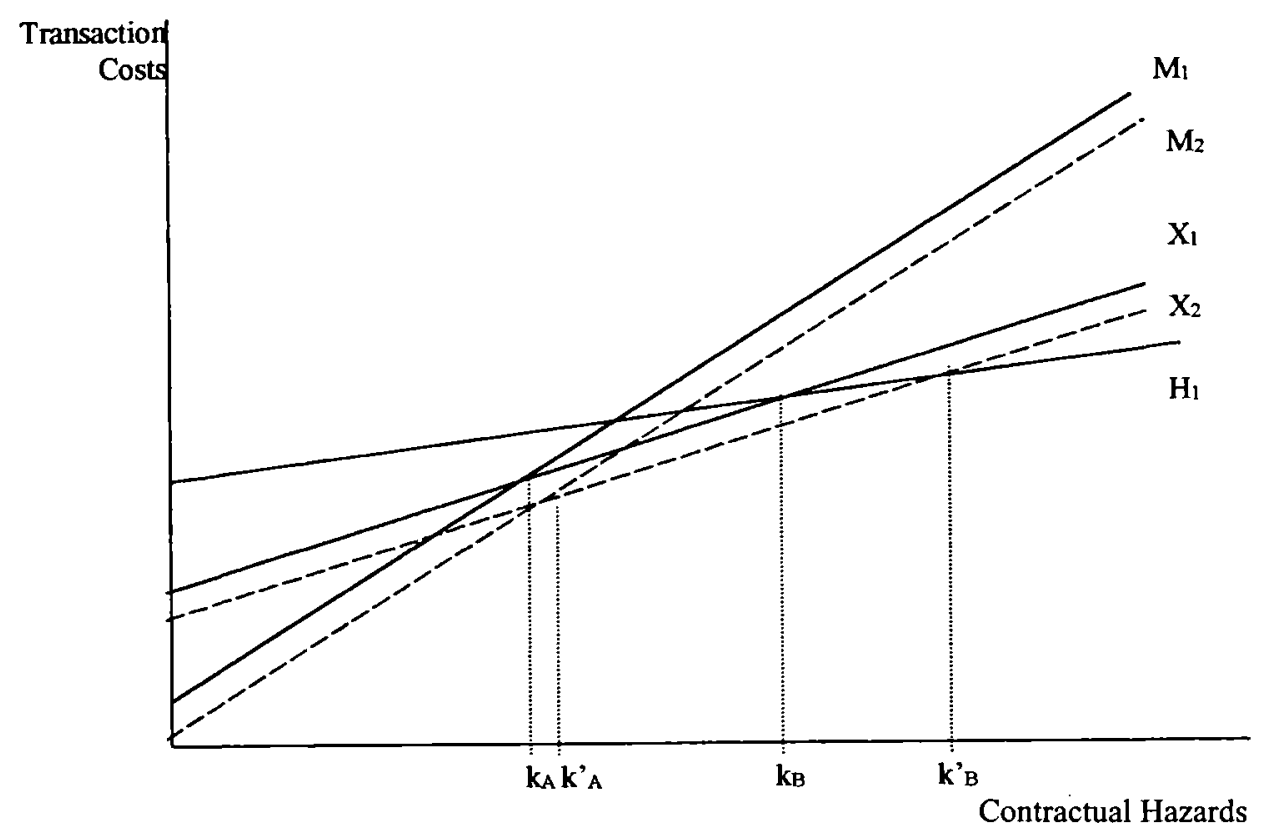

FIGURE 1. The simple shift parameter framework.

8. See Teece (1986a), Grandy (1989), Henisz and Zelner (1999), and Keefer (1996). 
run the risk that knowledge of innovations will leak out. ${ }^{9}$ Such firms will organize more economic activity internally, thereby to reduce the hazard of leakage. The downward shift of market and hybrid governance curves in Figure 1 can be interpreted as an improvement in the intellectual property rights, thereby supporting greater interfirm contracting.

The overall composition of investment and contracting will reflect changes of both investment and organizational kinds. ${ }^{10}$ Such considerations have begun to make their way into the public policy literature, especially in relation to the theoretical arguments and empirical evidence for differential efficacy of privatization and deregulation as a function of the institutional environment. ${ }^{11}$

A noteworthy feature of this literature is that nominal changes in contract and property rights laws do not necessarily imply effective changes. There is a need to go beyond the (nominal) laws on the books to consider the de facto laws, which brings in the credibility (or lack thereof) of the mechanisms of enforcement.

A related concern is to ascertain the ease with which even de facto changes in the law of property or contract can be reversed, which brings in the polity. Issues of credible commitment are posed. As Barry Weingast has put it, 'In important respects, the logic of political institutions parallels that of economic institutions. To borrow Williamson's phrase, the political institutions of society create a "governance structure" that at once allows the society to deal with on-going problems as they arise and yet provides a degree of durability to economic and political rights. Importantly, these help limit the ability of the state to act opportunistically'. ${ }^{12}$

Thus, whereas promises (mere words) are easy to utter, credible promises require more. Janos Kornai's observation that craftsmen and small shopkeepers fear expropriation in Hungary despite 'repeated official declarations that their activity is regarded as a permanent feature of Hungarian socialism' is pertinent. ${ }^{13}$ That 'many of them are myopic profit maximizers, not much interested in building up lasting goodwill ... or by investing in long-lived fixed assets ${ }^{\prime 14}$ is partly explained by the fact that 'These individuals or their parents lived through the era of confiscations in the forties'. ${ }^{15}$

But there is more to it than that. Not only is there a history of expropriation, but, as of 1986, the structure of the government had not changed in such a way as to assuredly forestall subsequent expropriations. Official declarations will be more credible only with long experience or if accompanied by a credible (not easily reversible) reorganization of politics. As one Polish entrepreneur once remarked, 'I don't want expensive machines. If the situation changes, I'll get

\footnotetext{
9. See Teece (1986a).

10. See Riordan and Williamson (1985) and Williamson (1991).

11. See Heller and McCubbins (1996), Henisz (1999a), Levy and Spiller (1994), Noll and Rosenbluth (1995), Ramamurti (1996), Willig (1994), and World Bank (1995).

12. Weingast (1993), p. 233.

13. Komai (1986), pp. 1705-1706.

14. Kornai (1986), p. 1706.

15. Kornai (1986), p. 1705.
} 
stuck with them'.$^{16}$ Note, in this connection, that the objectivity of the law is placed in jeopardy if the law and its enforcement are under the control of a one-party state. ${ }^{17}$ Credibility will be enhanced if a monarch who has made the law 'may not make it arbitrarily, and until he has remade it-lawfully-he is bound by it'. ${ }^{18}$ Self-denying ordinances and, even more, inertia that has been crafted into the political process, have commitment benefits. ${ }^{19}$

When credibility is absent, the state may need to become the fallback investor for durable, nonredeployable assets. Thus, whereas sometimes state ownership occurs because the state wants to be so engaged, sometimes it occurs by default: the risk-adjusted rate of return is so high that private investment cannot be supported. Indeed, that is precisely the argument of Levy and Spiller in their examination of privatization of telecommunications in five countries. ${ }^{20}$ When there is an absence of confidence in the independence and integrity of the judiciary, private investors run the risk that regulation will be arbitrary and capricious. Faced with those hazards, they will be prepared to pay little for pre-existing investments and will manage those investments with an emphasis on immediate returns. Such hazards are especially great in parliamentary regimes, where legislative and executive branches are under common control.

\section{Shift parameters for multinational corporations}

Our purpose here is to go beyond the simple shift parameter framework for domestic firms to include multinational firms and their relations with hostcountry partners as these are influenced by the property rights regime of a host country.

Informal (including language and cultural) differences in the institutional environment aside, if the formal institutional environment is identical (or very similar) in the host and home country, the multinational firm will decide the make or buy decision with primary reference to the same tradeoff in the host country as it does with home country suppliers. In that event, the argument from Section 2 carries over.

A substantial body of empirical work within international business has examined the question of appropriate governance for multinational subsidiaries through just such a comparative lens. These studies consistently find support for the proposition of a discriminating alignment between high contractual hazards and more hierarchical governance. ${ }^{21}$ Added complications appear, however, when the analysis is expanded to include host countries where the institutional environment differs substantially from the home country. And, of course, language or cultural differences that have economizing consequences need to be

16. New York Times, 25 October 1989, pp. A1, A10.

17. See Berman (1983), p. 37.

18. Berman (1983), p. 9.

19. See North and Weingast (1989).

20. See Levy and Spiller (1994).

21. See Blodgett (1991), Davidson and McFetridge (1985), Gatignon and Anderson (1988), Gomes-Casseres $(1989,1990)$, Hennart (1991), Hill et al. (1990), Hladik (1985), Kogut and Singh (1988), Murtha (1991), Oxley (1997, 1999), and Ramachandran (1993). 
factored into the choice of governance. ${ }^{22}$ We set the latter aside and focus on formal features.

In countries where the government's commitments to a given structure of taxation and/or regulation or even a set of property rights are easily changed, multinational corporations face added political hazards of two kinds. First, the government is more likely to behave in an opportunistic manner for its own benefit. Second, the host-country partner or a host-country competitor may opportunistically approach the government with requests to take actions that have the effect of favoring them at the expense of the multinational. We label these direct and indirect political hazards, respectively. In both of these cases, the multinational corporation faces added hazards relative to the host-country firm due to the differential access to the political process that arises by reason of nationality. Thus whereas opportunism that originates with the state and opportunistic use of the state are everywhere a concern, they are a special concern in cross-national contracting and investment.

Recent headlines provide examples of each of these hazards. Direct political hazards are of daily concern to foreign firms operating in Russia. Firms as diverse as General Electric and Ben \& Jerry's have recently pulled out of the country, citing arbitrary and capricious taxation and regulation. Enterprising politicians are a chronic concern. Coca-Cola's St. Petersburg bottling plant was recently threatened with having its fire permit revoked, leading to a forced closure, awaiting a $\$ 1 \mathrm{~m}$ 'donation' to the local fire inspectorate for the construction of a new fire station. ${ }^{23}$

Indirect political hazards have also received much publicity recently, especially in regard to the lack of transparency in the newly struggling East Asian economies. The tax breaks and import protection provided to Indonesian President Suharto's son for the construction of a national car that severely disadvantaged the investments made by Japanese and European car companies under the assumption that they would receive the preferential terms are one example. Another comes from the Philippines where Hong Kong-based Hutchinson Ports has twice won bids over the Philippines-based ICTSI to operate a new container terminal at Subic Bay. The perception is that it would be able to handle a larger volume of cargo and begin operations more quickly. ICTSI, however, has twice successfully lobbied President Ramos to personally intervene and require an additional round of bidding. Hutchinson Ports' managing director John Meredith now believes that his company's bids will continue to be overturned until ICTSI wins. ${ }^{24}$

Given the presence of such political distortions and/or expropriation hazards, the multinational firm needs to examine: (1) whether partnering with a domestic supplier provides relief because the domestic supplier can beneficially influence political and regulatory practice; (2) whether the use of gray or black markets provides relief from the 'grabbing hand' of the state by making the transaction

22. See Davidson and McFetridge (1985), Hamilton and Biggart (1988), Kogut and Singh (1988), Loree and Guisinger (1995), and Shane (1992).

23. The Economist, 6 September 1997, p. 68.

24. The Economist, 1 February 1997, pp. 64-65. 
harder for public authorities to detect; and (3) whether such partnering or reliance on informal economic organization is fraught with added contractual hazards because partner and polity will prospectively work in concert to the disadvantage of the multinational.

One vein of literature advises multinational firms to acquire 'bargaining power' when confronted by direct political hazards. Firms with strong competitive advantages-due to unique technological resources, marketing skills, capital resources or scale economies-will possess a strategic advantage in negotiations with host-country governments. ${ }^{25}$ They will be better able to deal with host government controls over market access or propensities to subsidize domestic producers or competitors. ${ }^{26}$ The main conclusion from this literature is that expropriation hazards will be reduced if multinationals have relatively high bargaining power compared to the host-country government and can maintain that edge through strategic management of firm assets or through political lobbying. ${ }^{27}$

A problem with this argument is that $e x$ ante strategic bargaining advantages largely evaporate as soon as the multinational has made durable and immobile investments in the host country. ${ }^{28}$ Confronted with this prospect, multinational firms should look ahead and work out the organizational ramifications of such hazards. What direct and indirect (organizational) instruments will mitigate these hazards?

Partnering with a host-country firm is one possibility. Choices between and tradeoffs within legal and extra-legal modes of trading will need to be examined. Remaining within the legitimate (legal) sector, the main tradeoff to be faced is how much of an added stake should be awarded to host country workers, managers, and investors (over and above those that are warranted by 'simple' efficiency considerations) by reason of direct political hazards. The idea here is to reduce the hazards of political expropriation by loading a greater fraction of the costs of expropriation onto domestics to which the polity will be more deferential. $^{29}$

This deference derives from the higher political costs-unemployment, reduced tax revenue, political contributions and votes-and lower political benefits - through appeal to national pride and/or sovereignty-obtained in the expropriation of wholly or partly domestic partners as compared with entirely foreign firms (where the latter are normally assumed to use lower levels of domestic factors due to the 'liability of foreignness'). ${ }^{30}$ While assistance from the home country government, private-sector consultants and support from multilateral institutions may reduce these disadvantages, such relief is costly.

25. See Fagre and Wells (1982) and LeCraw (1984).

26. See Doz and Prahalad (1981), Gomes-Casseres (1990), and Murtha (1993).

27. See Poynter (1985).

28. See Vernon (1971) and Teece (1986b).

29. This hypothesis is strongly supported by the only available empirical study, which was conducted by Bradley (1977). The author finds that expropriation of joint ventures exclusively between foreign multinationals is eight times as likely as expropriation of joint ventures that involve local partners.

30. See Zaheer (1995). 
A wide body of empirical evidence supports the proposition that, ceteris paribus, local partners will be more likely to receive a share of equity ownership in countries with high political hazards. ${ }^{31}$ Note that from the perspective of the multinational firms this involves a less hierarchical governance structure.

Recourse to illegitimate (gray market or black market) trading is another option. To be sure, this poses hazards of its own. Some transactions, however, may be easy to disguise or hide, whereupon they can be placed outside the reach of oppressive regulation/taxation/bureaucratization/manipulation. Theoretical work by Bannerjee, ${ }^{32}$ Che and Qian, ${ }^{33}$ and Hay et al.,${ }^{34}$ support the proposition that firms faced with political hazards have greater recourse to illegitimate behavior. Qualitative studies by De Soto ${ }^{35}$ in Peru and Kaufman and Kaliberda ${ }^{36}$ and Black et al., ${ }^{37}$ in Russia on the prevalence of the underground economy in countries with predatory institutional environments is also corroborative. Preliminary quantitative work demonstrates that the use of trade credit in transition economies varies in both the perceived reliability of ex post enforcement mechanisms (confidence in the courts and membership in trade associations) and the accessibility of ex ante information (membership in relevant social and business network and geographic proximity. $)^{38}$

The above discussion links organizational choices to the level of a nation's political hazards, but the possibility that intrafirm and interfirm contractual hazards may be exacerbated by the polity also bears remark. In the degree to which partnering by a multinational with a local firm poses added hazards by reason of a compliant polity to which the local partner enjoys better access, the choice of governance will be tilted away from partnering in favor of vertical integration.

One example of such magnified contractual hazards is the ongoing shareholder dispute in the Russian firm of Novolipetsk. A group of foreign investors-who, along with Russian partners, own $40 \%$ of the firm's equity-have been stymied in their attempts to nominate board members. Documents sent by the group are repeatedly not received or miss the deadline despite the contrary evidence of registered mail and courier service receipts. Dimitry Vasiliev, chairman of the Federal Securities Commission claims 'At the moment, I have insufficient enforcement powers. I cannot fine directors or put them in jail'; he says 'shareholders must decide these questions in civil courts'. Needless to say, the Russian managers and workers who own the remaining $60 \%$ of the equity are taking advantage of the lack of enforcement powers by the Securities Commission to secure benefits for themselves through the use of hidden financial

31. See Agarwal and Ramaswami (1992), Brouthers (1995), Gatignon and Anderson (1988), Goodnow and Hansz (1972), Kogut and Singh (1988), Oxley (1999), Phillips-Patrick (1991), Scholhammer and Nigh (1984), and Shane (1992).

32. See Banerjee (1997).

33. See Che and Qian (1998).

34. See Hay et al. (1996).

35. See DeSoto (1989).

36. See Kaufman and Kaliberda (1996).

37. See Black et al. (1999).

38. See Johnson et al. (1999). 


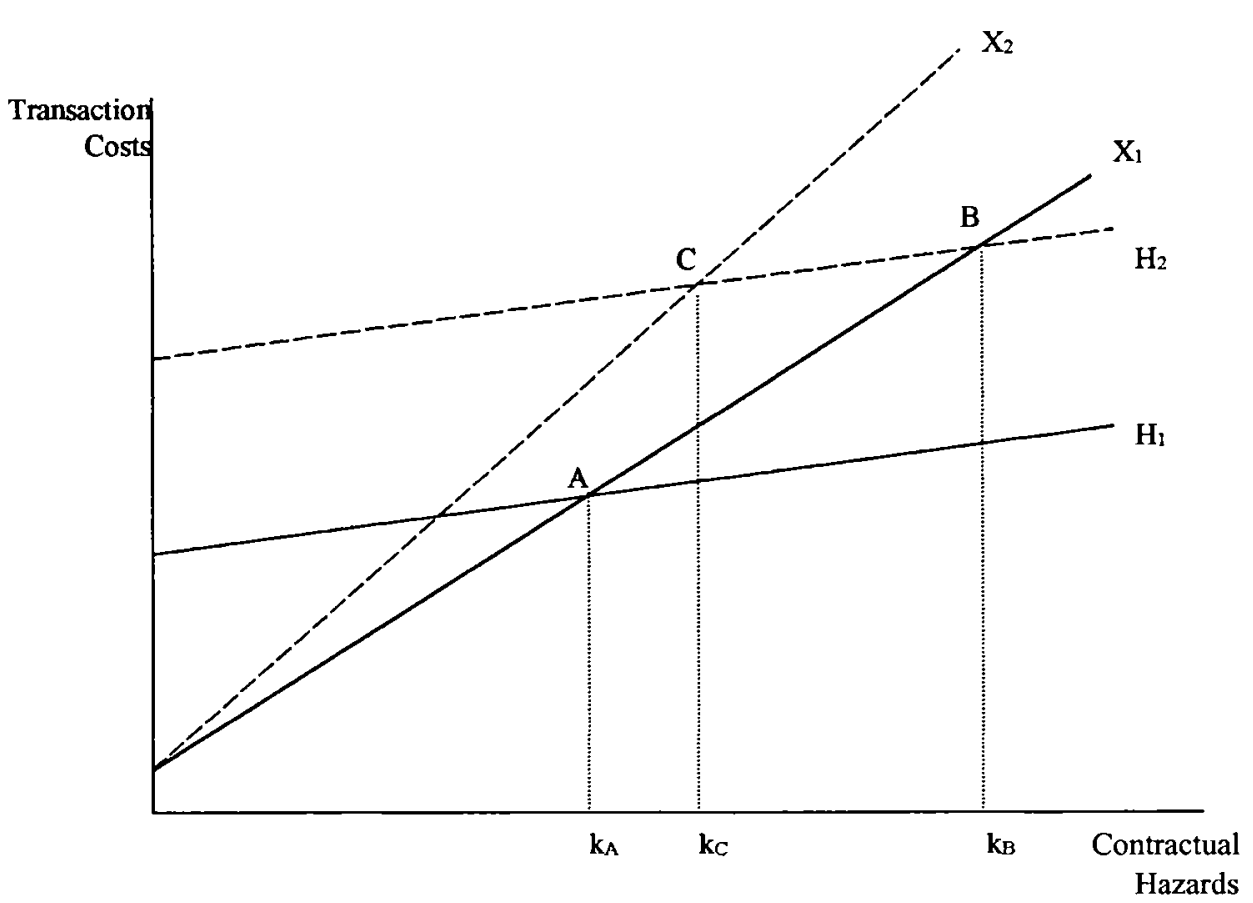

FIGURE 2. Political hazards, contractual hazards and governance.

accounts and the awarding of supply contracts to their confederates on the basis of terms other than price and quality.

In a heuristic way, the relations are as shown in Figure 2, where the level of contractual hazards (as indexed by the condition of asset specificity) is on the horizontal axis and the transaction costs of contract $(X)$ and ownership $(H)$ are shown on the vertical axis. The reference condition, where the property rights regime is the same in the multinational's home country and in the host country, is shown by subscript 1 . Added direct political hazards in the host country increase the cost of ownership, which is shown as a vertical displacement from $H_{1}$ to $H_{2}$. The displacement is vertical as assets of all types are equally affected by the potential for arbitrary and capricious government action of the type faced by Ben \& Jerry's or Coca Cola in Russia.

Indirect political hazards posed by the partnering firm in the host country increase the cost of contracting in an amount proportional to the level of contractual hazards posed by the transaction and are shown as a rotation of $X_{1}$ to $X_{2}$. In this case, the magnitude of the increase in governance costs is not independent of the level of contractual hazards. Where the potential returns to opportunistic behavior are high, the creation of an additional (non-market) mechanism by which the host country partner may act to the detriment of their foreign partner increases the hazards faced by the multinational firm by relatively more than in the absence of contractual hazards.

For example, consider the case of two firms seeking to establish a manufacturing operation in a country with a strong property rights regime. One firm 
employs a generic production technology and the second a firm-specific technology safeguarded in the home country through trade secrets. Despite the differences in their production technologies and the threat of technological leakage, both firms receive sufficient value from their local partners in terms of local information that they minimize governance costs in the host country by partnering. As the low level of political hazards implies a low probability of achieving a change in the current policy regime, neither local partner finds lobbying host-country political actors for a policy intervention that would alter the distribution of returns between the local partner and the multinational to have a positive expected value. If political hazards increase in the host country, both operations face the threat that the government will alter tax, regulatory or other relevant policies to their detriment. However, the incentives faced by the two local partners differ substantially. In the first case, the local partner may find it advantageous to lobby the government for changes in policy that change the distribution of returns between the multinational and the local partner. However, in the second case, the local partner may seek not only to shift the distribution of returns but also to manipulate the political system in a way that transfers ownership of a potentially rent-generating technology from the multinational to the local partner. The incentives for opportunistic behavior in the non-market arena are clearly larger in the latter case. Ceteris paribus, the governance costs for partnerships should increase by a larger amount for transactions with higher levels of contractual hazards (in this case, a firm-specific production technology) as compared to transactions with lower levels of contractual hazards (in this case, a generic production technology).

Returning to Figure 2, the upshot is that:

(1) contract (partnering) is the least cost mode under the reference condition $\left(H_{1}, X_{1}\right)$ up to value $k_{\mathrm{A}}$, but gives way to ownership as contractual hazards continue to increase beyond $k_{\mathrm{A}}$;

(2) direct political hazards increase the attractiveness of partnering up to the level of $k_{\mathrm{B}}\left(H_{2}, X_{1}\right)$;

(3) indirect political hazards reduce the attractiveness of partnering back to the level of $k_{\mathrm{C}}\left(\mathrm{H}_{2}, X_{2}\right)$.

Though we have shown point $\mathrm{C}$ (and $k_{\mathrm{C}}$ ) to fall on the right of point $\mathrm{A}$ (and $k_{\mathrm{A}}$ ), such that a weakening of the property rights regime leads to an increase in the range of transactions for which partnering is the least cost governance mode, point $\mathrm{C}$ (and $k_{\mathrm{C}}$ ) may also be on the left of point $\mathrm{A}$ (and $k_{\mathrm{A}}$ ). In this case, a weakening of the property rights regime would lead to a decrease in the range of contractual hazards for which partnering is the least cost governance mode. The actual direction of this shift will depend on the slopes of the $X$ and $H$ schedules and the magnitude of their shift and rotation (which reflect the relative magnitude of direct and indirect political hazards faced by the multinational firm and the relationship between these hazards and transaction costs).

While we are unable to make definitive predictions regarding the impact of a weakening of the property right regime on the range of transactions over which partnering will be favored in a given country, we are able to make specific predictions regarding the impact of such an decrease in credibility on transac- 
tions with low as compared with high contractual hazards. For the sake of expositional convenience, consider the transaction with contractual hazards given by $k_{\mathrm{A}}{ }^{39}$ Under the reference condition $\left(H_{1}, X_{1}\right)$ the transaction costs associated with organizing this transaction as a partnership and a wholly owned enterprise are identical $\left(T C\left(H_{1}\left(k_{\mathrm{A}}\right)=T C\left(X_{1}\left(k_{\mathrm{A}}\right)\right)\right.\right.$. However, after the weakening of the property rights regime $\left(H_{2}, X_{2}\right)$, it is now cost effective to organize the transaction $k_{\mathrm{A}}$ by supplanting ownership by partnership $\left(T C\left(H_{2}\left(k_{\mathrm{A}}\right)<T C\left(X_{2}\left(k_{\mathrm{A}}\right)\right)\right.\right.$. Now consider the transaction with contractual hazards given by $k_{\mathrm{C}}$. Initially, transaction costs were minimized under ownership $\left(T C\left(H_{1}\left(k_{\mathrm{C}}\right)<T C\left(X_{1}\left(k_{\mathrm{C}}\right)\right)\right.\right.$. However, after the weakening of the property rights regime, the transaction costs associated with partnership $\mathrm{X}_{2}$ and ownership $\mathrm{H}_{2}$ are identical $\left(T C\left(H_{2}\left(k_{\mathrm{C}}\right)=T C\left(X_{2}\left(k_{\mathrm{C}}\right)\right)\right.\right.$.

Regardless of the relative location of point $C$ and point $A$, it will be true that at sufficiently low levels of contractual hazards a weakening of the property rights regime will increase the attractiveness of partnership. However, as the level of contractual hazards increases, the strength of this relationship will diminish and could even be such that ownership is increasingly attractive. The main result that emerges from our analysis is that the impact of variation in property rights regimes either across countries or over time on the relative costs of governance of partnership and ownership will depend crucially on the level of contractual hazards posed by the individual transaction.

Earlier research on the origins of the multinational corporation concluded that the same assets which provide multinational corporations economic advantage over host country competitors give rise to contractual hazards in relations with local trading partners. ${ }^{40}$ In that event, the high contractual hazards that are endemic in the overseas operations of multinational corporations make it likely that some multinationals will respond to the presence of political hazards by eschewing partnerships with host country firms. ${ }^{41}$

Empirical tests of this theory require two types of data: first, a measure of the institutional environment of a given country in a given year which centers upon the notion of credible commitment; and, second, measures of contractual hazards in the operations of multinational corporations. As it turns out, much of the empirical work cited above fails to provide either or both of these measures. ${ }^{42}$ Recent empirical analyses by Henisz, ${ }^{43}$ Murtha, ${ }^{44}$ and Oxley ${ }^{45}$ demonstrate that

39. Note that given the magnitude of the shift and rotation employed here, $k_{\mathrm{A}}$ (the intersection between the original partnership and ownership schedules) is sufficiently low to pose a contrast to $k_{\mathrm{B}}$. While this may not always be the case, there will always be some level of contractual hazards sufficiently low such that the governance costs of partnership are reduced relative to ownership.

40. See Buckley and Casson (1976) and Caves (1996) for excellent reviews of the determinants of internationalization.

41. Note that the foregoing assumes that the level of contractual hazards (the value of $k$ ) is given. In fact, $k$ is a decision variable and will be chosen (in part) with reference to the condition of political hazards. This introduces added complications which, for the purposes of this paper, are treated as second order and are ignored.

42. See Note 31 .

43. See Henisz (1999b, 1999c).

44. See Murtha (1991).

45. See Oxley $(1997,1999)$. 
suitable measures of both the institutional environment and of contractual hazards are available and do support the theoretical predictions that we have set forth herein. Specifically, the theoretical framework that we present offers differential predictions as to how multinational firms investing in countries with weak property rights regimes will alter the governance of their transactions characterized by relatively low vs high contractual hazards. In countries with relatively weak property rights regimes or countries suffering a weakening of said regimes, the probability that a transaction will be organized under partnership increases for transactions with low contractual hazards while it increases for transactions with low contractual hazards while it decreases for transactions with high contractual hazards.

\section{An application to recent economic crises}

An important component of recent economic crises in such countries as Thailand, Russia and Brazil has been the concern that actual policies, as opposed to ex ante pledges, may benefit insiders at the expense of local or international investors that lack political connections. In other words, the perceived strength of the property rights regime has decreased dramatically in many emerging markets. The theoretical arguments that we have developed lead to several predictions regarding the impact of differentiated hazards on investment and contracting in countries with varying levels of exposure to multinational corporate activity.

In economies where multinational activity plays a relatively small role such as Russia, the primary impact of a perceived weakening of the property rights regime will be a reduction in the level of investment and an increase in the reliance by domestic firms upon the internal provision of intermediate inputs so as to avoid the higher perceived costs of using the courts or other official third party dispute resolution mechanisms when disagreements with suppliers arise. Alternatively, firms may eschew formal markets and rely more heavily on gray or black market activity and/or enforcement mechanisms. ${ }^{46}$

While the magnitude of investment-especially in durable, nonredeployable assets-will similarly decline in more open economies such as Brazil or Thailand, the impact of a similar weakening of the property rights regime on the organization of economic activity is more complex in these cases. Specifically, for those transactions where the risk of expropriation by a counter-party is low due to the generic or easily imitable nature of the relevant technology or the lack of reliance by the multinational parent on a brand name reputation that may be degraded by the counter-party, weakening of the property rights regime should lead to a higher degree of reliance on domestic counter-parties (see the preceding discussion of point $k_{\mathrm{A}}$ in Figure 2). These partners will provide the multinational parent with assistance in navigating the increasingly muddy waters of the domestic political arena. However, where the nature of the technology employed or the susceptibility to free-riding yields concerns regarding private expropriation hazards, the potential benefits obtained from counter-parties in the political arena could be more than offset by the danger that they will manipulate the play

46. See Braguinsky (1999). 
in that political system to their advantage (see the preceding discussion of point $k_{\mathrm{C}}$ in Figure 2).

In circumstances where there has been a dramatic short-term weakening of the property rights regime, researchers who are able to identify well-designed measures of contractual hazards, such as those developed by Murtha ${ }^{47}$ and Oxley, ${ }^{48}$ should be able to separately observe the two distinct effects of property rights regimes on the organization of activity that we describe.

\section{Conclusion}

The upshot is that the bottom-up view out of which transaction cost economics works can tell us a good deal about the condition of the institutional environment and its impact on the organization of economic activity. Analysis may be pursued both within or between countries, on domestic or multinational investors. In each case the discriminating alignment between the level of hazards (contractual and/or political) and the mode of governance is prominently featured.

Within a country, the choice of governance mode (market, hybrid or hierarchy) is mainly determined by the attributes of transactions. Allowing for change in a given country over time or comparing domestic investors in two countries, more credible institutional environments support more complex economic transactions and modes of governance. Finally, extending the analysis to include the multinational corporation introduces the need to adapt the choice of governance mode in a given country to take into account the level of both contractual and political hazards.

The relationship between these hazards is not, however, simply additive. That is because the influence of political hazards on the cost and competences of different organizational reforms operates through both direct (state-sector opportunism) and indirect (opportunistic use of the state) channels. Substantial variation in both sets of hazards, such as is provided in the open economy context (especially when extended to emerging markets), may be needed in order to empirically identify these individual effects.

Inasmuch as the action resides in the details, this conceptual framework needs to be joined by deep local knowledge of both the governance of international transactions and the nature of political hazards. That combination is precisely what is in progress, as witness the recent transaction level analysis of the contractual hazards faced by multinational corporations developed in Murtha ${ }^{49}$ and Oxley, ${ }^{50}$ which offer substantial improvements upon prior firm-level analysis. Similar micro-analytic improvements in the measurement of property rights regimes provided by the host country government are also required.

When joined with appropriate industry- or country-specific knowledge, the

47. See Murtha (1991).

48. See Oxley (1997).

49. See Murtha (1993).

50. See Oxley (1997). 
'relentlessly calculative and comparative approach to economic organization ${ }^{\text {,51 }}$ offered by transaction cost economics can provide substantial insight into the reasons for differences in the structure of economic activity both across countries and over time.

\section{References}

Agarwal, Sanjeev and Sridhar N. Ramaswami. 1992. Choice of Foreign Market Entry Mode: Impact of Ownership, Location and Internalization Factors. Journal of International Business Studies 23(1): 1-27.

Banerjee, Abhijit. 1997. A Theory of Misgovernance. Quarterly Joumal of Economics 112(4): 1289-1332. Berman, Harold Joseph. 1983. Law and Revolution: The Formation of the Western Legal Tradition. Cambridge, MA: Harvard University Press.

Black, Bernard, Reinier Kraakman and Anna Tarassova. 1999. Russian Privatization and Corporate Governance: What Went Wrong? Unpublished manuscript, Harvard University, Cambridge, MA.

Blodgett, Linda Longfellow. 1991. Partner Contributions as Predictors of Equity Share in International Joint Ventures. Journal of International Business Studies 22(1): 63-78.

Bradley, David. 1977. Managing Against Expropriation. Harvard Business Review July-August: 75-83.

Braguinsky, Serguey. 1999. Enforcement of Property Rights During the Russian Transition: Problems and Some Approaches to a New Liberal Solution. Journal of Legal Studies 28(2): 515-544.

Brouthers, Keith D. 1995. The Influence of International Risk on Entry Mode Strategy in the Computer Software Industry. Management Intermational Review 35(1): 7-28.

Buckley, Peter J. and Mark C. Casson. 1976. The Future of the Multinational Enterprise. London: Homes and Meier.

Caves, Richard E. 1996. Multinational Enterprise and Economic Analysis. Cambridge: Cambridge University Press.

Che, Jiahua and Yingyi Qian. 1998. Insecure Property Rights and Government Ownership of Firms. Quarterly Journal of Economics 113(2): 467-496.

Commons, John R. 1932. The Problem of Correlating Law, Economics and Ethics. Wisconsin Law Review 8: 3-26.

Crocker, Keith J. and Scott E. Masten. 1996. Regulation and Administered Contracts Revisited-Lessons from Transaction-Cost Economics for Public Utility Regulation. Journal of Regulatory Economics 9(1): 5-39.

Davidson, William H. and Donald G. McFetridge. 1985. Key Characteristics in the Choice of International Technology Transfer Mode. Journal of International Business Studies 16(2): 5-21.

De Soto, Hemando. 1989. The Other Path: The Invisible Revolution in the Third World. New York: Harper \& Row.

Doz, Yves and C. K. Prahalad. 1981. How MNCs Cope with Host Country Intervention. Harvard Business Review March-April: 149-157.

Fagre, Nathan and Louis T. Wells. 1982. Bargaining Power of Multinational and Host Governments. Journal of International Business Studies 13(2): 9-23.

Galanter, Marc. 1981. Justice in Many Rooms, Private Ordering and Indigenous Law. Journal of Legal Pluralism 19: 1-47.

Gatignon, Hubert and Erin Anderson. 1988. The Multinational Corporation's Degree of Control over Foreign Subsidiaries: An Empirical Test of a Transaction Cost Explanation. Journal of Law, Economics and Organization 4(2): 305-336.

Gomes-Casseres, Benjamin. 1989. Ownership Structures of Foreign Subsidiaries. Journal of Economic Behavior and Organization 11(1): 1-25.

Gomes-Casseres, Benjamin. 1990. Firm Ownership Preferences and Host Government Restrictions. Journal of International Business Studies 21(1): 1-23.

Goodnow, James D. and James E. Hansz. 1972. Environmental Determinants of Overseas Market Entry Strategies. Journal of International Business Studies 3: 33-50.

Grandy, Christopher. 1989. Can the Govemment Be Trusted to Keep its Part of a Social Contract? New Jersey and the Railways, 1825-1888. Journal of Law, Economics and Organization 5(2): 249-269.

51. Williamson (1996), p. 8. 
Hamilton, Gary G. and Nicole W. Biggart. 1988. Market, Culture and Authority: A Comparative Analysis of Management and Organization in the Far East. American Joumal of Sociology 94(S): 52-94.

Hay, Jonathan R., Andrei Shleifer and Robert Vishny. 1996. Toward a Theory of Legal Reform: Privatization in Transition Economies. European Economic Review 40(3-5): 559-567.

Heller, William B. and Mathew D. McCubbins. 1996. Politics, Institutions and Outcomes: Electricity Regulation in Argentina and Chile. Journal of Policy Reform 1(4): 357-388.

Henisz, Witold Jerzy. 1999a. 'The Institutions and Governance of Economic Reform': Theoretical Extentions and Applications. Public Management 1(3): 369-392.

Henisz, Witold Jerzy. 1999b. The Institutional Environment for Economic Growth. Economics and Politics forthcoming.

Henisz, Witold Jerzy. 1999c. The Institutional Environment for Multinational Investment. Unpublished manuscript, University of Pennsylvania, Philadelphia PA.

Henisz, Witold Jerzy and Bennet A. Zelner. 1999. The Institutional Environment for Telecommunications Investment. Unpublished manuscript, University of Pennsylvania, Philadelphia PA.

Hennart, Jean-Francois. 1991. The Transaction Costs Theory of Joint Ventures: An Empirical Study of Japanese Subsidiaries in the United States. Management Science 37(4): 483-497.

Hill, Charles W. L., Peter Hwang and W. Chan Kim. 1990. An Eclectic Theory of the Choice of International Entry Mode. Strategic Management Joumal 11(2): 117-128.

Hladik, Karen J. 1985. International Joint Ventures. Washington D.C.: Heath and Company.

Johnson, Simon, John McMillan and Christopher Woodruff. 1999. Contract Enforcement in Transition. Unpublished manuscript, University of California, San Diego CA.

Kaufman, Daniel and Aleksander Kaliberda. 1996. Integrating the Unofficial Economy into the Dynamics of Post-Socialist Economies: A Framework of Analysis and Evidence. In Economic Transition in Russia and the New States of Eurasia, edited by Bartlomiej Kaminski. Armonk, NY: M.E. Sharpe.

Keefer, Philip. 1996. Protection Against a Capricious State: French Investment and Spanish Railroads, 1845-1875. Journal of Economic History 56(1): 170-192.

Klein, Benjamin, Richard G. Crawford and Armen A. Alchian. 1978. Vertical Integration, Appropriable Rents and the Competitive Contracting Process. Journal of Law and Economics 21(2): 297-326.

Kogut, Bruce and Harbir Singh. 1988. The Effect of National Culture on the Choice of Entry Mode. Journal of International Business Studies 19(3): 411-432.

Kornai, Janos. 1986. The Hungarian Reform Process: Visions, Hopes and Reality. Journal of Economic Literature 24(4): 1687-1737.

LeCraw, Donald. 1984. Bargaining Power, Ownership and Profitability of Transnational Corporations in Developing Countries. Journal of International Business Studies 15(1): 27-42.

Levy, Brian and Pablo T. Spiller. 1994. The Institutional Foundations of Regulatory Commitment: A Comparative Analysis of Telecommunications Regulation. Journal of Law, Economics and Organization 10(2): 201-246.

Loree, David W. and Stephen E. Guisinger. 1995. Policy and Non-policy Determinants of U.S. Equity Foreign Direct Investment. Journal of International Business Studies 26(2): 281-299.

Lyons, Bruce R. 1995. Specific Investment. Economies of Scale, and the Make-or-Buy Decision: A Test of Transaction Cost Theory. Journal of Economic Behavior and Organization 26(3): 431-443.

Murtha, Thomas. 1991. Surviving Industrial Targeting: State Credibility and Public Policy Competencies in Multinational Subcontracting. Journal of Law, Economics and Organization 7(1): 117-143.

Murtha, Thomas. 1993. Credible Enticements: Can Host Governments Tailor Multinational Firms' Organizations to Suit National Objectives? Journal of Economic Behavior and Organization 20(2): 171-186.

Noll, Roger G. and Frances M. Rosenbluth. 1995. Telecommunications Policy: Structure, Process, Outcomes. In Structure and Policy in Japan and the United States, edited by Peter Cowhey and Mathew McCubbins, pp. 119-176. New York: Cambridge University Press.

North, Douglass C. and Barry R. Weingast. 1989. Constitutions and Commitment: The Evolution of Institutions Governing Public Choice in Seventeenth Century England. Journal of Economic History 49(4): 803-832.

Oxley, Joanne Elizabeth. 1997. Appropriability Hazards and Governance in Strategic Alliances: A Transaction Cost Approach. Journal of Law, Economics and Organization 13(2): 387-409.

Oxley, Joanne Elizabeth. 1999. Institutional Environment and the Mechanisms of Governance: The Impact of Intellectual Property Protection on the Structure of Inter-firm Alliances. Journal of Economic Behavior and Organization 38(3): 283-310. 


\section{Comparative Economic Organization}

Phillips-Patrick, Frederick J. 1991. Political Risk and Organizational Form. Journal of Law and Economics 34(2 (part 2)): 675-693.

Poynter, Thomas A. 1985. Multinational Enterprises and Government Intervention. New York: St. Martin's Press.

Ramachandran, Vijaya. 1993. Technology Transfer, Firm Ownership and Investment in Human Capital. Review of Econom ics and Statistics 75(4): 664-670.

Ramamurti, Ravi. (Ed.) 1996. Privatizing Monopolies: Lessons from the Telecommunications and Transport Sectors in Latin America. Baltimore: Johns Hopkins University Press.

Riordan, Michael and Oliver Williamson. 1985. Asset Specificity and Economic Organization. International Journal of Industrial Organization 3(4): 365-378.

Scholhammer, Hans and Douglas Nigh. 1984. The Effects of Political Events on Foreign Direct Investments by German Multinational Corporations. Management International Review 24(1): 18-40.

Shane, Scott A. 1992. The Effect of Cultural Differences in Perceptions of Transaction Costs on National Differences in the Preference for Licensing. Management International Review 32(4): 295-311.

Shelanski, Howard and Peter Klein. 1995. Empirical Research in Transaction Cost Economics: A Review and Assessment. Joumal of Law, Economics and Organization 11(2): 335-361.

Teece, David J. 1986a. Profiting from Technological Innovation: Implications for Integration, Collaboration, Licensing and Public Policy. Research Policy 15(6): 285-305.

Teece, David J. 1986b. Transaction Cost Economics and the Multinational Enterprise: An Assessment. Journal of Economic Behavior and Organization 7(1): 21-45.

Vernon, R. 1971. Sovereignty at Bay: The Multinational Spread of U.S. Enterprises. New York: Basic Books.

Weingast, Barry. 1993. Constitutions as Governance Structures: The Political Foundations of Secure Markets. Journal of Institutional and Theoretical Economics 149(1): 286-311.

Williamson, Oliver E. 1975. Markets and Hierarchies: Analysis and Antitrust Implications: A Study in the Economics of Internal Organization. New York: The Free Press.

Williamson, Oliver E. 1991. Comparative Economic Organization: The Analysis of Discrete Structural Alternatives. Administrative Science Quarterly 36(2): 269-296.

Williamson, Oliver E. 1996. The Mechanisms of Governance. New York: Oxford University Press.

Willig, Robert D. 1994. Public versus Regulated Private Enterprise. Proceedings of the World Bank Annual Conference on Development Economics, 1993: 155-180.

World Bank. 1995. Bureaucrats in Business: The Economics and Politics of Government Ownership. New York: Oxford University Press.

Zaheer, Srilata. 1995. Overcoming the Liability of Foreignness. Academy of Management Journal 38(2): 341-363. 
Brought to you by | University of Pennsylvania

Authenticated

Download Date | 6/7/16 4:14 PM 